\title{
ECONOMIC PRESSURE AS A MEANS OF PRE- SERVING PEACE
}

\author{
By Herbert S. Houston, \\ Treasurer, League to Enforce Peace, New York.
}

At the meeting of the Academy a year ago there was serious and scholarly discussion of the results in commerce, in government and in human progress that would follow from the great war. Today that war still continues and, at the moment, we ourselves seem to be at its very brink. And so we come again, at this meeting of the Academy, to consider the questions that confronted and disturbed us a year ago.

At such a time it may require a brave spirit to look through battle smoke to hills of hope beyond on which shall rise, some day, world courts of justice, following the orderly processes of law. But that was the dream of Penn, in whose city we gather. It was the dream of Hugo Grotius, of Emanuel Kent and of hundreds of others, all through the generations. And two months after our meeting of last April, there gathered in this city of Penn, several hundred men who had the faith to believe that the great dream might come true and the courage to plan definitely to that end. As was fitting, they assembled in Independence Hall and there formulated the proposals of the League to Enforce Peace. Here was a mighty challenge flung in the face of a warring world-a challenge to establish peace, when the war ends, on a basis of justice and to maintain it through courts, upheld by international agreements and made effective by international forces. And these proposals have received broad popular support. The Chamber of Commerce of the United States appointed a committee to study the economic results of the war and to consider plans for a lasting peace. After a careful survey of all the plans for peace this committee submitted the proposals of the League as constituting the wisest and most

${ }^{1}$ The proceedings of this meeting appeared in the following volumes of The Annals: Vol. LX, July, 1915, "America's Interests as affected by the European War"; and Vol. LXI, September, 1915, "America's Interests after the European War." 
practicable that had been formulated, and the hundreds of constituent commercial bodies in the National Chamber, with several hundred thousand members, voted in favor of them by a great majority; in fact all but one of the four proposals received a majority in excess of two thirds. Last October the International Peace Congress, in session in San Francisco, embodied these proposals in its platform; and peace societies in Massachusetts, in New York, in Pennsylvania and throughout the country have taken similar action. Many church associations have given their support, as have the economic societies in various cities. Recently in New York the Executive Committee of the League met in conference with the leaders of the Security League, the Navy League and of other preparedness organizations and it was discovered that they were practically of one mind in favoring national defense for America and international peace for the world, resting on law and on courts. Right now the Associated Advertising Clubs are carrying forward a nation-wide publicity campaign under that shibboleth "National Defense and International Peace," in support of the 30,000 engineers who, during last May, made a card-index survey of industry so that it may be mobilized for defense, if need comes. In the coming national political conventions the proposals of the League to Enforce Peace will be presented for adoption in party platforms. All this is a record of things done, or now in hand to do, in furtherance of a plan to secure world peace that has been formulated since the last meeting of the Academy. I submit that it is a cheerful record, in a time of war and rumors of war, and that it gives some ground for the hope that wars may be reduced in number in the future, if not wholly done away with.

A year ago ${ }^{2}$ I referred briefly to a resolution that had been presented before the Chamber of Commerce of the United States, favoring the use of economic pressure as a force to further world peace. Today I can say boldly that that view has the support of the business men of America. By an overwhelming majority, in the referendum of which I have made mention, they favored the use of a "System of commercial and financial non-intercourse" against nations which, after joining with other nations in setting up courts,

¿See The Annals, Vol. LXI, September, 1915, p. 272. 
persisted in going to war before taking their international differences to these courts for decision.

Let us briefly examine commerce as economic pressure. Of what does it consist and how could it be applied? The most effective factors in world-wide economic pressure, such as would be required to compel nations to take justiciable issues to a World Court for decision, are a group of international forces. Today money is international because in all civilized countries it has gold as the common basis. Credit based on gold is international. Commerce based on money and on credit is international. Then the amazing network of agencies by which money and credit and commerce are employed in the world are also international. Take the stock exchanges, the cables, the wireless, the international postal service and the wonderful modern facilities for communication and intercommunication-all these are international forces. They are common to all nations. In the truest sense they are independent of race, of language, of religion, of culture, of government, and of every other human limitation. That is one of their chief merits in making them the most effective possible power used in the form of economic pressure to put behind a World Court.

Business today is really the great organized life of the world. The agencies through which it is carried forward have created such a maze of interrelations that each nation must depend on all the others. A great Chicago banker, John J. Arnold, Vice-President of the First National Bank of that city, said to me a few weeks ago that so closely drawn and interwoven had become the economic net in which the world was enmeshed that if the great war could have been postponed four or five years it would never have swept down upon men like a thunderbolt of destruction. As an additional strand of great strength in the warp and woof of modern progress, Mr. Arnold believes that an International Clearing House will come -in fact that it is an inevitable development in international finance, for settling balances between nations, just as our modern clearing houses now settle balances between banks in cities in which they are located. Beyond question such an International Clearing House, when established, would quickly become an invaluable auxiliary to a World Court, helping to give it stability and serving, when occasion arose, as a mighty agency through which economic pressure could be applied. 
And I believe Mr. Arnold is right in his view that an International Clearing House is bound to come. Business, finance, and commerce are now so truly international that there is a manifest need of it. As a strong proof of this let me remind you that when this war broke, 40 per cent of the securities of the world were held internationally.

Now economic pressure is not a new thing in the world. It has been used before by one nation against another and usually with tremendous effectiveness. When Philip was organizing the great armada the merchants of London persuaded the merchants of Genoa to withhold credit and moneys from the Spanish King. The result was that the armada was delayed for over a year, and then the English were prepared to meet the shock. What could be done three centuries ago for a year to delay a Power so great as Spain then was could be done in this century far more effectively. And it has been employed in this century. When the German Emperor dispatched the gunboat to Agadir bringing on the acute crisis with France, I happened to be in Paris. On the fourth day of the crisis I was having luncheon at the Grand Hotel with a young French banker of the Credit Lyonnais. I remarked on the fact that the crisis was becoming less acute and inquired the reason. "We are withdrawing our French investments from Germany," was the rejoinder "and that economic pressure is relieving the situation." As we all know, it not only relieved the situation but it served as a definite means to prevent a war that seemed imminent. Now I submit that a force which England could use against Spain in the sixteenth century and that France could use against Germany in the twentieth century -in each case let me remind you a single nation was applying force against another single nation and that nation its enemy-I submit that that force can be applied by all nations collectively against another nation that refuses to take a justiciable issue to a World Court for a decision.

A nation that should decline to take justiciable questions to the World Court, after having agreed with other nations to do so, would manifestly become an outlaw. Why shouldn't other nations immediately declare an embargo of non-intercourse with an outlaw nation, refusing to buy from that nation or to sell to that nation or have any intercourse whatsoever with that nation? 
One of the great advantages of economic pressure is that it can be applied from within, rather than from without. Economic pressure touches the war chest of every country. Instead of fighting with bullets we can fight also with the money and credit that must be behind bullets. And the world can fight in that way to protect the civilization that has been slowly and painfully built up through the centuries if it will use the force of commerce that stands ready to its hand. Nations can declare an economic embargo against an offending nation. Or it is more accurate to say the offending nation raises an economic embargo itself by its own act in breaking its pledge to other nations and placing itself outside the pale of civilization by becoming an outlaw.

Of course, the one apparently strong and valid argument to be brought against economic pressure is that it would bring great loss to the commerce of the nations applying it. But that loss would be far less than the loss brought by war. And there would be no loss whatever if war were avoided.

If a balance could be rightly struck in this country is there any one who believes that our interests would be best served by war in some other country? This is quite apart from any question of humanity or civilization. Let it be a trial balance of commerce alone and it will show a heavy debit against war. And an accounting will show the same result in all other countries. If this be true, with only current commerce entering into the equation, how staggeringly true it becomes when the piled up debts caused by war are considered. Economists who have examined the matter state that this war has already cost over sixty billions of dollars. And the end is not yet.

So why shouldn't business, which has been binding the world more closely together for centuries, be employed to protect the world against the waste and loss of war? The loss in trade would be small or great in proportion to the amount and duration of the pressure; but it would be at most only an infinitesimal fraction of the loss caused by war. The League to Enforce Peace stands for the use of both economic and military power against a nation that goes to war before submitting any question arising to the international court. If the question is submitted and decision rendered the nation can go to war if it is so disposed, but the League believes that it will not be so disposed. Instead, in the time required for submitting the 
question to the court and getting a decision a nation will, as a rule, have its war fever cooled and its calmness restored, with the result that the court's decree will be accepted. There is not a case on record of a nation refusing to abide by an arbitration decision, in all the arbitrations that have been held in the last century. So if nations can be brought before an international tribunal the record shows that decrees will be obeyed and wars avoided. 